\title{
Pterygium excision with conjunctival autograft using autologous in SITU blood coagulum as bioadhesive
}

\author{
B. Asritha ${ }^{1}$, D. Manaswini² \\ ${ }^{1}$ Dr. B. Asritha, Assistant Professor, ${ }^{2}$ Dr. D. Manaswini, Post graduate; both authors are attached with Department of \\ Ophthalmology, Narayana Medical College and Hospitals, Nellore, Andhra Pradesh, India.
}

Corresponding Author: Dr. B. Asritha, Assistant Professor, Department of Ophthalmology, Narayana Medical College and Hospitals, Nellore, Andhra Pradesh, India. E-mail: b.asritha@gmail.com

\begin{abstract}
Aim: To evaluate the outcomes of pterygium excision with conjunctival autograft using autologous in situ blood coagulum. Materials and Methods: This is a prospective study of 50 eyes of 50 patients after taking informed consent, operated between May 2017 and October 2018 in the Department of Ophthalmology, Narayana Medical Hospital, Nellore. The study included 21 males and 29 females. Following pterygium excision, $1 \mathrm{~mm}$ oversized donor conjunctival graft was taken and placed over bare sclera, maintaining limbus to limbus polarity. The surgeon waited for 5-7 minutes to allow time for hemostasis and stabilization of graft. Results: Complications observed were graft edema in 4 cases (8\%), graft retraction in 1 case $(2 \%)$, subgraft haemorrhage in 2 cases $(4 \%)$. Commonly encountered complications were subconjunctival haemorrhage, chemosis, congestion, discomfort, corneal scarring, corneal epithelial defects, and inadequate sized grafts. Recurrence or dehiscences were not noted. Conclusion: This study of using autologous blood coagulum for pterygium fixation showed this method to be more effective, less time consuming than suturing grafts, and more economical and free from the risk of contagious diseases compared to fibrin glue. The occurrence of very minimal complications and the swift resolution of any encountered complications makes this a superior approach.
\end{abstract}

Keywords: Pterygium, Conjunctival autograft, Bioadhesive, In situ blood coagulum

\section{Introduction}

Pterygium is a triangle shaped degenerative and hyperplastic process occurring medially and laterally in the interpalpebral aperture in which the bulbar conjunctiva encroaches onto the cornea [1]. Its prevalence rates vary widely from $2-29 \%$ and are higher in tropics than at temperate latitudes [2-4].

Pterygium is graded based on its extension over the cornea [5]:

Grade I- Head upto limbus.

Grade II- Head between limbus and point midway between limbus and papillary margin.

Grade III- Head between a point midway between limbus and papillary margin and papillary margin.

Grade IV-Head crossing the papillary margin.

Many pterygia remain asymptomatic. Surgery is indicated whenocular irritation, discomfort, watering,

Manuscript received: $30^{\text {th }}$ May 2019

Reviewed: $8^{\text {th }}$ June 2019

Author Corrected: $15^{\text {th }}$ June 2019

Accepted for Publication: $19^{\text {th }}$ June 2019 foreign body sensation, photophobia, recurrent inflammation, reduced visual acuity due to obstruction of visual acuity or astigmatism (hypermetropic +0.75 to +1.5 ), cosmetic disfigurement, and/or diplopia due to restriction of ocular movements develop. Difficulty in contact lens fitting and performing corneal refractive surgeries are other indications for surgery [6].

Most methods for small primary pterygium involve simple excision. For larger and recurrent pterygia, goal of treatment is to prevent recurrence. Recurrence rates of older techniques were high; $50 \%$ recur in 4 months and nearly all recurred in 1 year [7].

Currently, most widely used techniques are conjunctival autografting and mitomycin $\mathrm{C}$ application [8]. Human amniotic membrane grafts have also been shown to be effective [9]. Fibrin based glues for conjunctival autografting have been used to minimize operating time and post-operative discomfort associated with sutures, and reduced the amount of suturing required [10]. 


\section{Original Research Article}

Although fibrin glues improved patient comfort and showed low recurrence rates compared to suturing, the risk of transmitted disease from pooled and single donor blood donors is a major drawback to its application $[11,12]$.

Hence, the novel approach of using the patient's own serum as bio-adhesive was chosen and outcomes were evaluated in the present study.

The aim of the present study is to evaluate the outcomes of pterygium excision with conjunctival autograft using autologous in situ blood coagulum.

\section{Materials and Methods}

Setting: Department of Ophthalmology, Narayana Medical Hospital, Nellore.

Type of study: Prospective study of 50 eyes of 50 patients operated between May 2017 and October 2018 in the Department of Ophthalmology, Narayana Medical Hospital, Nellore.

Inclusion Criteria- Patients of all ages and both sexes with primary nasal pterygium were included in the study.

Exclusion Criteria- Eyes with active infection or inflammation

Temporal pterygium

Recurrent pterygium

History of previous ocular surgeries or trauma

Pseudopterygium

HIV/Hepatitis B

Bleeding disorders

Written and informed consent were taken from all patient. Pre-operative ocular examination was done, including refraction with best corrected visual acuity, slit lamp biomicroscopy, IOP measurement, and fundus examination.
Surgical Techniques: All patients were operated by single surgeonunder peribulbar anaesthesia. Under aseptic precautions, eye speculum was placed. Neck of the pterygium was lifted and peeled off along with head in a sweeping fashion. Body of pterygium was then separated from sclera beneath and excised, avoiding insertion of medial rectus muscle.

Remnants of conjunctival tissue on cornea was scraped off using crescent blade in order to make the surface smooth. Size of bare sclera was measured using casteroviejo callipers. No cautery was used throughout the procedure and excess bleeding was avoided by using cotton bud as tamponade.

Corneal care was taken using viscoelastic substances. Donor conjunctival graft was taken from superior conjunctival area. About $1 \mathrm{~mm}$ oversized graft wasobtained, avoiding button holes and Tenon's capsule. Graft was placed over bare sclera, maintaining limbus to limbus polarity, and the surgeon paused for 57 minutes to allow time forhemostasis and stabilization of graft. Graft was secured well and did not require suturing.

The overall time taken for surgery was about $18 \pm 2$ minutes. Eye was then patched for the next 24 hours. Patch was removed the next day (first post-operative day) and assessed for symptoms like watering, pain, and foreign body sensation, and position of graft and any complications. E/drops Gatifloxacin 6 times/ day and E/drops Prednisolone 6 times/day were prescribed, and tapered over the next 6 weeks. E/d Carboxymethylcellulose 1\% 4 times/day for 6 weeks was used as lubricant.

Patient was followed up later on $7^{\text {th }}$ POD, $45^{\text {th }}$ POD, and after six months. In each visit, patient was assessed for subgraft haemorrhage, graft edema, graft retraction, graft dislodgement, and recurrence. Distant visual acuity was recorded on the $45^{\text {th }}$ POD.

Results of the study parameters before and after the treatment were expressed in mean values and were analysis carried out in a simple MS excel sheet.

\section{Results}

A total of 50 eyes of 50 patients underwent pterygium excision and conjunctival autograft with age between 20-60 years. The study included 21 males and 29 females (Table 1). Pterygia of Grade I-III were included in the study (Table 3).

Most common indication of surgery is foreign body sensation (23), followed by cosmetic disfigurement (20), and visual impairment (7) (Table 3). 
Table-1: Sex Distribution of Cases

\begin{tabular}{|c|c|}
\hline & Number of cases \\
\hline Males & 21 \\
\hline Females & 29 \\
\hline
\end{tabular}

Table-2: Grading of Pterygium Included in the Study.

\begin{tabular}{|c|c|c|c|c|c|}
\hline & Grade I & Grade II & Grade III & Grade IV & Total \\
\hline Males & 1 & 12 & 8 & 0 & 21 \\
\hline Females & 3 & 16 & 10 & 0 & 29 \\
\hline
\end{tabular}

Table-3: Indications for Surgery.

\begin{tabular}{|c|c|c|}
\hline & Male & Female \\
\hline Foreign body sensation & 11 & 12 \\
\hline Cosmetic disfigurement & 8 & 5 \\
\hline Visual impairment & 2 & 12 \\
\hline
\end{tabular}

Table-4: Complications Observed during the Study

\begin{tabular}{|c|c|c|c|}
\hline & Male & Female & Total \\
\hline Graft edema & $2(4 \%)$ & $2(4 \%)$ & $4(8 \%)$ \\
\hline Subgraft haemorrhage & $1(2 \%)$ & $1(2 \%)$ & $1(4 \%)$ \\
\hline Graft retraction & - & $1(2 \%)$ & $1(2 \%)$ \\
\hline
\end{tabular}

Complications observed were graft edema in 4 cases (8\%), graft retraction in 1 case (2\%), subgraft haemorrhage in 2 cases (4\%) (Table 4), and no recurrence or dehiscence was noted. Other commonly encountered complications were subconjunctival haemorrhage, chemosis, congestion, discomfort, corneal scarring, corneal epithelial defects, and inadequate sized grafts.

Excessive postoperative bleeding and gaping of the edges of the graft were not seen. Donor-site complications or transplant necrosis were not seen. These were not included in the results of the study because they are shared complications to conventional pterygium excision and may also be due to surgeon's error.

Table-5: Improvement in Visual Acuity Preoperatively vs. Postoperatively (45 ${ }^{\text {th }}$ POD)

\begin{tabular}{|c|c|c|}
\hline Lines of Snellen Acuity Changed & Number of cases & Percentage of cases (\%) \\
\hline-1 & 2 & 4 \\
\hline 0 & 28 & 22 \\
\hline+1 & 11 & 18 \\
\hline+2 & 9 & 56 \\
\hline
\end{tabular}

The majority of cases $(56 \%)$ did not have improvement in distant visual acuity on $45^{\text {th }} \mathrm{POD}$, most probably owing to the earlier grades of pterygia operated, which do not cross the pupillary border. $22 \%$ of cases showed a one-line improvement on Snellen's chart and 18\% showed two lines of improvement, owing to relative relief from the previous astigmatism. Two cases showed a one-line reduction in Snellen's visual acuity, which may be attributed to excessive corneal scarring. 


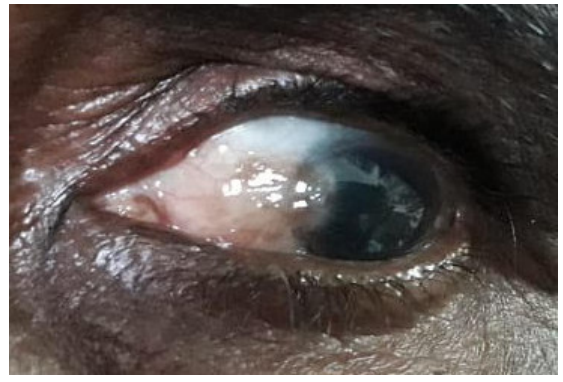

Figure-1:Pre-op photograph of Grade II pterygium in a female patient
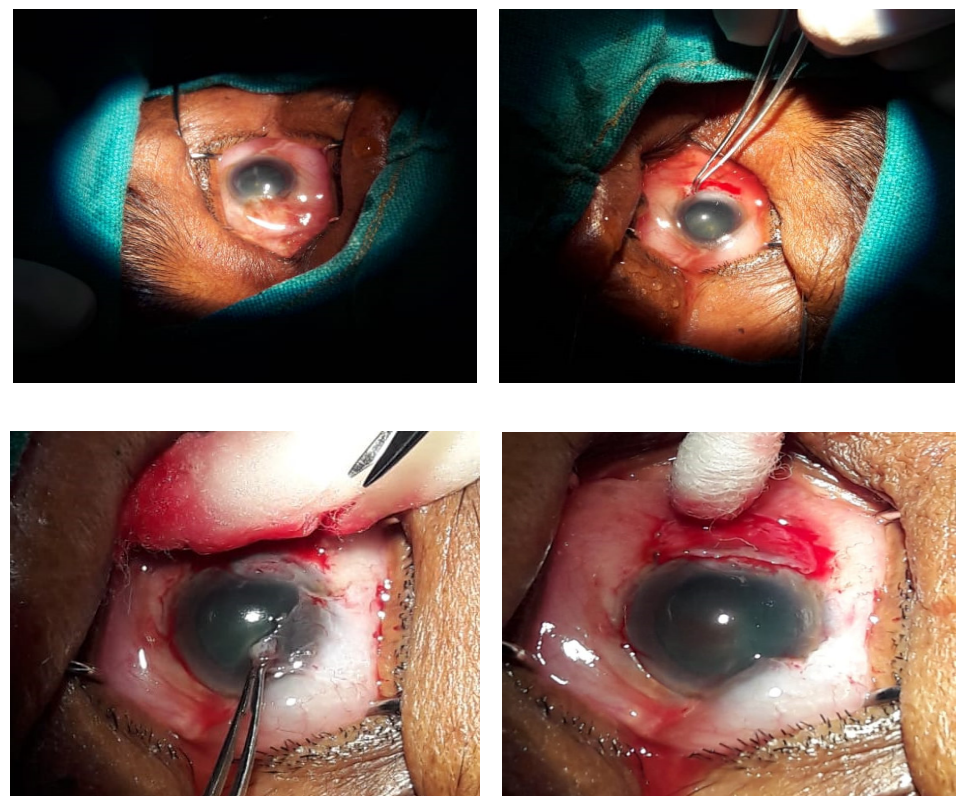

Figure-2: Intra- op photographs of the same patient
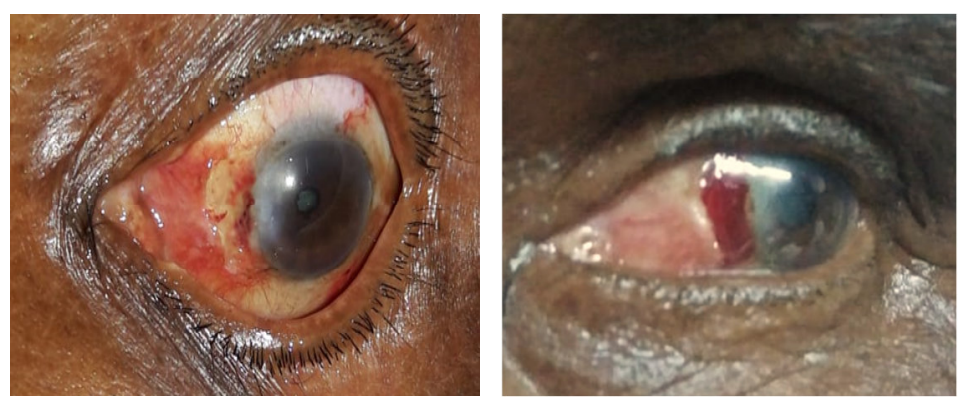

Figure-3:First post-operative day and $7^{\text {th }}$ POD of the same patient showing subgraft haemorrhage
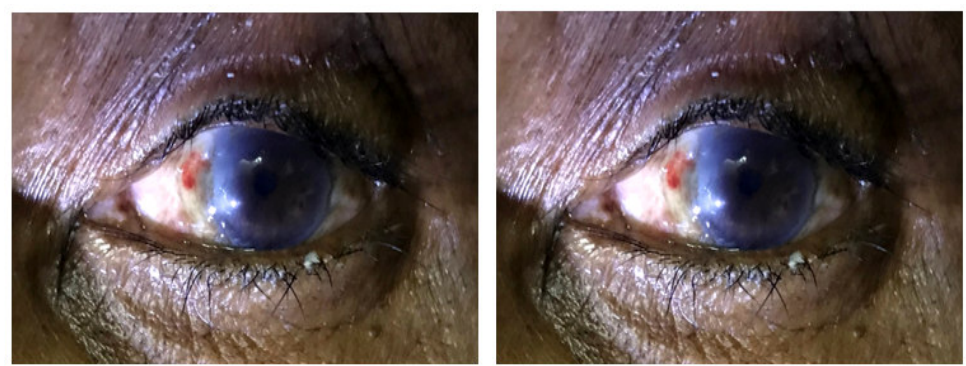

Figure-4:45 ${ }^{\text {th }}$ POD of the same patient showing resolved haemorrhage. 

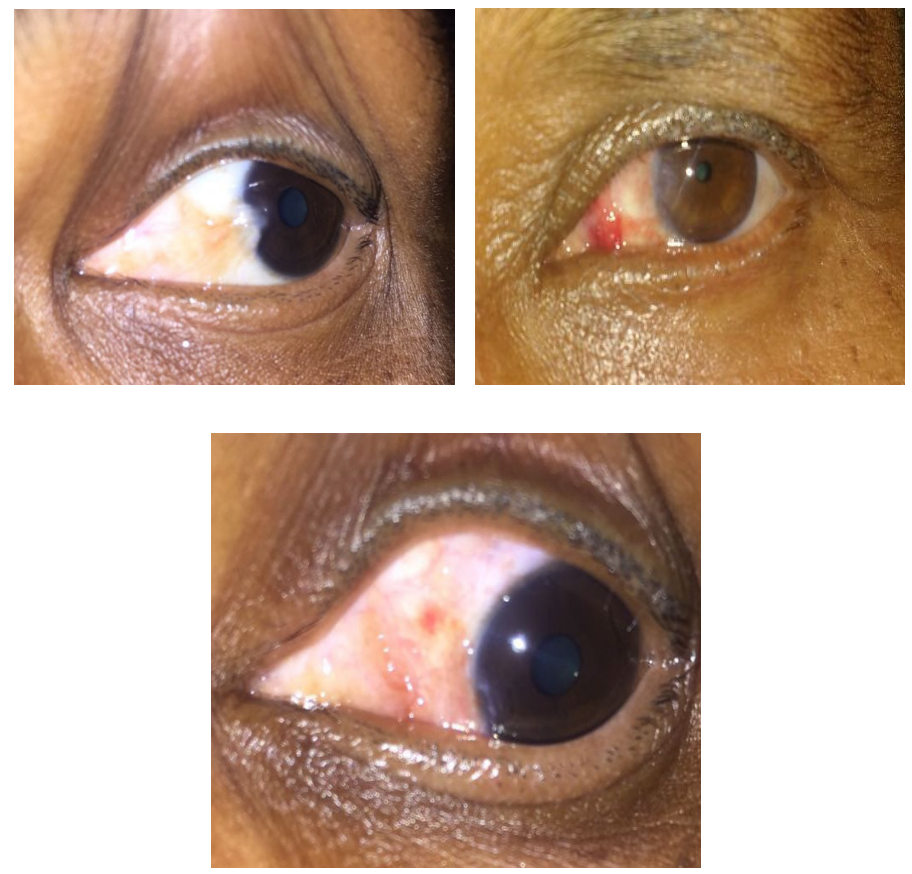

Figure 5: Pre-operative, $7^{\text {th }}$ POD, and $45^{\text {th }}$ POD photograph of a female patient with Grade I pterygium.

\section{Discussion}

The major hurdles of pterygium surgery in modern days are prevention of recurrences and complications, along with facilitation of speedy recovery post-operatively. Current surgical methods used to prevent recurrence are conjunctival autograft, limbal conjunctival autograft, conjunctival rotation autograft, amniotic membrane graft, lamellar keratoplasty and use of fibrin glue [13]. All the above techniques use sutures/fibrin glue and, therefore, are vulnerable to complications and unsatisfaction from the patient's side.

The most common method of autograft fixation is suturing, with drawbacks complications include infection, prolonged operating time, postoperative discomfort, suture abscess, button holes, pyogenic granuloma, which usually requires second surgery for removal, and chronic inflammation $[14,15]$.

Replacing sutures with tissue adhesives may shorten the operating time, improve postoperative comfort, andavoid suture related complications. However, the major concern of the commercial fibrin glue is the cost and the potential risk of transmitted infection [16].

Residual foreign body sensation of the operated eye is a drawback. Although fibrin glue avoids suture related complications, it carries risk of transmitting prion disease from the donor. Fibrin glue has been shown to be superior to sutures in securing a conjunctival autograft in terms of patient's comfort and lower recurrence rates. The success of sutureless and glue free limbal conjunctival autograft for the management of primary pterygium. The results of these studies were very encouraging as they suggested that suture less and glue free limbal conjunctival autografting following pterygium excision is a simple, safe, effective, without many complications and economical option for the management of primary pterygium [17].

Plasma-derived fibrin glue has the potential risk of prion disease transmission and anaphylaxis in susceptible individuals [18].

In this study, recurrence was not observed in any of the patients. Where as in other studies, post operative recurrence was observed in the first 6 weeks. The average surgical time taken was least with fibrin glue. In other study, postoperative discomfort was seen maximum in the suture group and was minimal in the fibrin glue group. At the end of final follow-up at 6 months, one case of recurrence was seen in both Group I and Group II [19]. Tiet alshowed that postoperative inflammation increases the risk of pterygium recurrence $[20,21]$.

Use of patient's own blood for fixation of a conjunctival autograft is a novel approach which prevents the above complications. None of the patients in our study showed recurrence. Studies reported by Kultheetal and Sharma et alare comparable with the presentstudy [22,23]. In 


\section{Original Research Article}

Kul the et alstudy, 79 eyes were operated in a sutureless and glue-free surgical technique there were no recurrences by the end of 6 months. Sharma et al operated on 50 eyes with primary pterygium using blood as a sealant and encountered no recurrences. Both studies support our study and statement that gluefree and sutureless approach is highly effective in preventing recurrences and cost effective by reducing the additional surgical supplies and assistance needed.

De Wit et al [1] studied 15 eyes of sutureless pterygium technique, and concluded that the procedure is a simple technique for pterygium surgery and may prevent potential adverse reactions encountered with the use of foreign materials.

In Mitra et al study, 19 patients underwent graft fixation with autologous blood, and showed no losses or recurrences, similar to our study[17]. Nadarajah et al, in a comparative study of autologous blood and fibrin glue usage in pterygium surgery, reported 2(3.4\%) recurrences occurred in the fibrin adhesive method and $5(10.6 \%)$ recurrences occurred in the autologous blood method. However, this was not statistically significant in their study and, hence, did not rule out autologous blood as sealant in being effective in preventing recurrent pterygia [19].

Elwan SA compared two groups of patients treated for primary pterygium one group sutured and the other was sutureless after pterygium excision, the study concluded that the sutureless and glue free technique is easy, safe, and prevents the potential adverse complications of suture materials. The recurrence rate was $8 \%$ in the sutured group compared to $6 \%$ in the non-sutured group [24].

Sharma etalobserved the efficacy of non-sutured pterygium surgery and concluded that the technique is an effective and safe option for primary pterygium. The recurrence rate was $1.25 \%$, and Tenon's granuloma was reported in $1.25 \%$ ( 1 case).

Rathi et al observed 50 eyes in which pterygium excision was followed by sutureless glue free conjunctival graft, recurrence developed in 1 eye $(2 \%)$, graft loss in 1 eye $(2 \%)$ and chemosis in 2 eyes $(4 \%)[25]$.

Graft edema was noted in 4 patients on first POD,owing to excessive surgical manipulation, inclusion of Tenon's capsule in the graft, or poor graft orientation. This was, however, completely resolved at the 1 week follow up. Subgraft haemorrhage was noted in 2 patients on

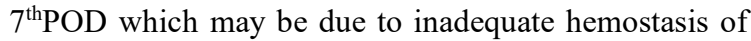
episcleral or conjunctival vessels, andgraduallyresolved by 4 weeks. One patient had graft retraction on the $7^{\text {th }}$ POD which may be as a result of inadequate size of the graft, excess Tenon's tissue, or poor quality of graft, which resolved without any consequences. Although graft retraction was encountered, recurrence was not seen at 6 months postoperative time.

In Kumar et al comparative study, postoperative discomfort was more in the suture group than the autologous blood group [26]. Pterygium excision, being a relatively simple surgery, requires absolute complication-free outcomes and high patient satisfaction. Sutures, however effective they are in securing the grafts, fail in achieving this goal. The present study aims not only to prove that sutureless technique prevents long term complications, but also becomes the patients' approval.

The presence of sutures is associated with various complications, i.e. discomfort, increased lacrimation, and at times suture-related granuloma or abscess. With the invention of newer alternatives such as fibrin glue and autologous blood, suture-related complications have come to a halt. The use of fibrin glue during pterygium surgery was first described by Cohen and Mc Donald in 1993 [27]. Since then, various studies have been published regarding the safety and efficacy of fibrin glue in ophthalmic surgery. As the fibrin glue is a blood-derived product, its use is associated with the risk of transmission of blood-related diseases.

In these cases, autologous blood is a good alternative as it is easily available, only exception being patients who regularly take aspirin or other blood thinners or who suffer from a coagulation factor deficiency [28-30].

Fibrin glue is an effective approach to attach the conjunctival autografts and prevent recurrences. However, the cost and availability of fibrin glue is a hindrance. Also, the risk of transmission of diseases poses a threat. No other major complications were noted in our study.

\section{Conclusion}

This study of using autologous blood coagulum for pterygium fixation showed this method to be more effective than suturing grafts and more economical and freefrom the risk of contagious diseases compared to fibrin glue. Moreover it is less time consuming with minimal complications and has excellent postoperative outcome, making it superior to other procedures. 


\section{Original Research Article}

\section{Funding: Nil, Conflict of interest: Nil \\ Permission from IRB: Yes}

\section{References}

1. Duke-Elders. St Louis - Textbook of Ophthalmology Mosby; 1954.

2. Ang LP, Chua JL, Tan DT. Current concepts and techniques in pterygium treatment. Curr Opin Ophthalmol. 2007 Jul;18(4):308-13. DOI:10.1097/ICU. 0b013e 3281a7ecbb

3. Gazzard G, Saw SM, Farook M, et al. Pterygium in Indonesia: prevalence, severity and risk factors. $\mathrm{Br} \mathrm{J}$ Ophthalmol.2002 Dec;86(12):1341-6. DOI:10.1136/bjo. 86.12 .1341

4. Luthra R, Nemesure BB, Wu SY, et al. Frequency and risk factors for pterygium in the Barbados Eye Study. Arch Ophthalmol. 2001 Dec;119(12):1827-32.

5. Maheshwari S. Effect of pterygium excision on pterygium induced astigmatism. Indian Journal of Ophthalmology. 2003 Jun 1;51(2):187.

6. Smolin G, Foster CS, Azar DT, Dohlman CH, editors. Smolin and Thoft's the cornea: scientific foundations and clinical practice. Lippincott Williams \& Wilkins; 2005.

7. Hirst LW, Sebban A, Chant D. et al. Pterygium recurrence time.Ophthalmology.1994 Apr;101(4):755-8

8. Chen PP, Ariyasu RG, Kaza V, et al. A randomized trial comparing mitomycin $\mathrm{C}$ and conjunctival autograft after excision of primary pterygium. Am J Ophthalmol. 1995 Aug;120(2):151-60.

9. Ma DH, See LC, Liau SB, et al. Amniotic membrane graft for primary pterygium: comparison with conjunctival autograft and topical mitomycin $\mathrm{C}$ treatment. Br J Ophthalmol. 2000 Sep; 84(9): 973-8. DOI: 10. 1136/bjo.84.9.973

10. Uy HS, Reyes JM, Flores JD, et al. Comparison of fibrin glue and sutures for attaching conjunctival autografts after pterygium excision. Ophthalmology. 2005 Apr;112(4):667-71. DOI: 10.1016/j.ophtha.2004. 08.028

11. Everts PA, Knape JT, Weibrich G, et al. Plateletrich plasma and platelet gel: a review. J Extra Corpor Technol. 2006 Jun;38(2):174-87.
12. Aizawa P, Winge S, Karlsson G. et al. Large-scale preparation of thrombin from human plasma. Thromb Res. 2008;122(4):560-7. doi: 10.1016/j.thromres. 2007. 12 .027. Epub 2008 Mar 10.

13. Ang LP, Chua JL, Tan DT. Current concepts and techniques in pterygium treatment. Curr Opin Ophthalmol. 2007 Jul; 18(4):308-13. DOI:10.1097/ICU. 0b013e3281a7ecbb

14. Allan BD, Short P, Crawford GJ, et al. Pterygium excision with conjunctival autografting: an effective and safe technique. Br J Ophthalmol. 1993 Nov;77(11):698701. DOI:10.1136/bjo.77.11.698

15. Tan D. Conjunctival grafting for ocular surface disease. CurrOpinOphthalmol. 1999 Aug;10(4):277-81.

16. Malik KP, Goel R, Gutpa A, et al. Efficacy of sutureless and glue free limbal conjunctival autograft for primary pterygium surgery. Nepal J Ophthalmol. 2012 Jul-Dec; 4(2):230-5. doi: http://dx.doi.org/ 10. 3126 / nepjoph.v4i2.6537.

17. de Wit D, Athanasiadis I, Sharma A, et al. Sutureless and glue-free conjunctival autograft in pterygium surgery: a case series. Eye (Lond). 2010 Sep; 24 (9):1474-7. doi: 10.1038/eye.2010.75. Epub 2010 Jun 4.

18. Dorfman HS, Kennedy JE, Bird WC. Longitudinal evaluation of free autogenous gingival grafts. A four year report. J Periodontol. 1982 Jun;53(6):349-52. DOI:10.1902/jop.1982.53.6.349

19. Kumar S, Singh R. Pterygium excision and conjunctival autograft: A comparative study of techniques. Oman J Ophthalmol. 2018 May-Aug;11(2): 124-128. doi: 10.4103/ojo.OJO 62017.

20. Panda A, Kumar S, Kumar A, et al. Fibrin glue in ophthalmology. Indian J Ophthalmol. 2009 Sep-Oct;57 (5): 371-9. doi: 10.4103/0301-4738.55079.

21. Ti SE, Chee SP, Dear KB, et al. Analysis of variation in success rates in conjunctival autografting for primary and recurrent pterygium. Br J Ophthalmol. 2000 Apr;84(4):385-9. DOI:10.1136/bjo.84.4.385

22. Kulthe SB, Bhosale AP, Patil PU, et al. Is the Surgical Technique of a Sutureless and Glue-free Conjunctivo-limbal autograft after pterygium excision complications free? Available from: http://www. mjdrdypu. org/ text.asp?2015/8/3/308/157069. 
23. Sharma A, Raj H, Gupta A, et al. Sutureless and Glue-free Versus Sutures for Limbal Conjunctival Autografting in Primary Pterygium Surgery: A Prospective Comparative Study. J Clin Diagn Res. 2015 Nov; 9 (11): NC06-9. doi: 10.7860/JCDR/2015/ 15689. 6789. Epub 2015 Nov 1.

24. Elwan SA: comparison between sutureless and glue free versus sutured limbal conjunctival autograft in primary pterygium surgery. Saudi journal of ophthalmology, 2014; 28: 292-298.

25. Gunjan Rathi1, Jayesh Sadhu, Priya Joshiyara, H. D. Ahir, S. S. Ganvit, N. N. Pandya: Pterygium surgery suture less glue less conjunctival auto grafting. Int J Res Med, 2015; 4(1): 125-128

26. Panda A, Kumar S, Kumar A, et al. Fibrin glue in ophthalmology. Indian J Ophthalmol. 2009 Sep-Oct;57 (5): 371-9. doi: 10.4103/0301-4738.55079.
27. Cohen RA, McDonald MB. Fixation of conjunctival autografts with an organic tissue adhesive. Arch Ophthalmol. 1993 Sep;111(9):1167-8.

28. Mitra S. Autoblood as Tissue Adhesive for Conjunctival Autograft Fixation in Pterygium Surgery; Poster Presented at the Annual Meeting of the American Academy of Ophthalmology; 22-23 October 2011; Orlando, Fla.

29. Nadarajah G, Ratnalingam VH, Mohd Isa $H$. Autologous Blood Versus Fibrin Glue in Pterygium Excision With Conjunctival Autograft Surgery. Cornea. 2017 Apr; 36 (4):452-456. doi: 10.1097/ICO. 0000000 000001106.

30. Kumar S, Singh R. Pterygium excision and conjunctival autograft: A comparative study of techniques. Oman J Ophthalmol. 2018 May-Aug;11(2): 124-128. doi: 10.4103/ojo.OJO_6_2017.

\section{How to cite this article?}

B. Asritha, D. Manaswini. Pterygium excision with conjunctival autograft using autologous in SITU blood coagulum as bioadhesive. Trop J Ophthalmol Otolaryngol.2019;4(2):143-150.doi:10.17511/jooo.2019.i02.13 